\title{
LXXII. Lava found on the sands near Boulogne
}

\section{Robert Bakewell Esq.}

To cite this article: Robert Bakewell Esq. (1824) LXXII. Lava found on the sands near Boulogne , Philosophical Magazine Series 1, 64:320, 414-415, DOI: 10.1080/14786442408644631

To link to this article: http://dx.doi.org/10.1080/14786442408644631

曲 Published online: 27 Jul 2009.

Submit your article to this journal $2 \pi$

Џ Article views: 2

Q View related articles $₫$ 
414. Mr. Bakewell on Lava found on the Sands near Boulognc.

have belonged to a species not before described, and propose to denominate it Ichthyosaurus coniformis.

\section{Plate III.}

Fig. 6. (a.) Tooth of the natural size in situ.

7. do. magnified.

8. do. transverse section do.

[For the following note we are indebted to the Rev. Mr. Conybeare. -Evir.]

"In reference to this paper, Mr. Conybeare observes, that, judging from the data afforded by the present figures, the tooth ascribed to Ichthyosaurus coniformis does not appear to him to differ from those of $I$. comtmanis sufficiently to warrant the establishment of a new species:- the only differences described are a less degree of aduncation in the tooth, and a greater thickness in the dental bone; but as it should appear that Dr. Harlan drew his conclusions from comparison not with other actual specimens, but only with the engravings in the Geological Transactions, some hesitation must be felt in admitting them, especially as the aduncation of the teeth in $I$. communis is itself very slight; and the character of their striz is but faintly marked in many impressions of the lithographic plate in the Geological Transactions.

"Mr. Conybeare wishes, however, merely to postpone the adoption of this new species of Ichthyosaurzs until these points can be determined by the comparison of actual specimens, which he hopes to facilitate by transmitting some teeth, \&c. of the species previously ascertained, to America.

"The Saurocephalus does not yet appear to have been found in England, and forms an important addition to the very interesting class of fossil Sauri."

LXXII. Lava found on the Sands near Boulogne. By Robert Bakeweli, Esq.

\section{To the Editors of the Philosophical Magazine and Journal. Gentlemen,}

WHEN I was at Boulogne in September last, I was informed that masses of lava, of different sizes, were frequently found on the sands west of the harbour. M. Dutertre in the lower town had several specimens, from which he obligingly broke one to give me a part.

The lava is of a darkish gray colour, porous, but extremely hard, and filled with grains of olivine; it bears a close resemblance to the lava from the Puy de Nugerre in Auvergne, described in the second volume of my Travels in the Tarentaise, Sic., except that the latter contains no olivine, at least in those parts where I examined it. An inquiry suggests itself of some importance in Geology-Are these masses of lava which are left on the sands after high tides, merely fragments that have been thrown out as ballast somewhere on the coast? Or are they derived from volcanic rocks hitherto unnoticed in Britanny or Normandy, which, like those of Aurergne, may 
have been erupted from beneath the granite, and intermixed with it on the surface? If the latter, we may well conceive that fragments brought down by the rivers might be washed by the tides and currents as far west as Boulogne.

\section{Yours truly,}

Torrington Square, Dec. 10, 1824. RoBT. BAKEwELL.

P.S.-M. Dutertre had other specimens of a different character, of which the volcanic origin was more problematical: one semivitreous, containing globules of metallic tin. He had also a very large deep yellow topaz found on the shore.

LXXIII. Introduction to the Seventh Section of Bessel's Astronomical Observations.

[Concluded from p. 349.]

MESSRS. Rosenberger and Scherck have found the proba1 bic error of observation from very numerous comparisons, $=1^{\prime \prime} \cdot 541$, which determination may be assumed to belong to the zenith distance $45^{\circ}$; applying to this determination the increase of the probable error depending on the zenith distance, which has been given in the 7th article, the probable errors of an observation with Cary's circle will be for the zenith distances $\begin{array}{ccccccc}0^{\circ} \quad 45^{\circ} & 60^{\circ} & 65^{\circ} & 70^{\circ} & 75^{\circ} & 80^{\circ} & 85^{\circ} \\ = & \pm 1^{\prime \prime} \cdot 517 ; & 1^{\prime \prime} \cdot 541 ; & 1^{\prime \prime} \cdot 555 ; & 1^{\prime \prime} \cdot 562 ; 1^{\prime \prime} \cdot 585 ; & 1^{\prime \prime} \cdot 655 ; 1^{\prime} \cdot 775 ; & 2^{\prime \prime} \cdot 286 .\end{array}$

A former determination gave the probable error of a mean of four observations of a Urse Minoris in zenith distance $36^{\circ}=0^{\prime \prime} 6845$, likewise independent of the errors of division; according to the present determination, it would be $=0^{\prime \prime} \cdot 77$ : the difference may be accounted for by the uncertainty of the error of collimation involved in the second, and perhaps likewise by the greater care taken in observing the pole-star. Besides these contingent errors of observation, every zenith distance has the error arising from the peculiar error of the individual divisions on which they depend: this later one might have been entirely avoided, if these divisions had been determined directly by my method, as I first intended, but was prevented from doing by other business and by the- near prospect of obtaining Reichenbach's circle. The probable quantity of the remaining error of division is found by the zenith distances of the above-named 38 stars, measured in both positions of the instrument, to be $=1^{\prime \prime} \cdot 004$; so that the probable error of the mean of an observation made in the same pesition of the instrument, is $=\sqrt[V]{ }\left\{\left(1^{\prime \prime \cdot 004}\right)^{2}+\frac{s^{2}}{a}\right\} ;$ By this formula, the probable errors of the single determinations and the most probaly'e declinations have been computed as follow: 